\title{
Development of growth strategies for social enterprises
}

\author{
Chang-Lin Yang ${ }^{1,2, *}$, Leemen Lee ${ }^{1,2}$, Yun-Chen Lee ${ }^{1}$ \\ ${ }^{1}$ Department of Business Administration, Fu Jen Catholic University, New Taipei City, Taiwan \\ ${ }^{2}$ Social Enterprise Research Center, Fu Jen Catholic University, New Taipei City, Taiwan
}

\section{Email address:}

051125@mail.fju.edu.tw (C. L. Yang),081638@mail.fju.edu.tw (L. M. Lee), badm2063@mails.fju.edu.tw (Y. C. Lee)

To cite this article:

Chang-Lin Yang, Leemen Lee, Yun-Chen Lee. Development of Growth Strategies for Social Enterprises. International Journal of Economics, Finance and Management Sciences. Vol. 2, No. 1, 2014, pp. 16-21. doi: 10.11648/j.ijefm.20140201.13

\begin{abstract}
This study classifies different types of social enterprises to clarify the problems of different types and propose methods of improvement. This study divides social enterprises into four types: benchmark driven, profit seeking, self-sufficient and mission driven, based on business operating situation. Moreover, empirical research is conducted to demonstrate the social enterprise development diagram through in-depth interviews. The respondents were mainly senior managers and social entrepreneurs. According to the interview results, the main characteristics of SEs are: 1. must content with poor public understanding of social responsibility and the concept of social enterprises; 2. Most social enterprises operate alone and lack group strength; 3. Most social enterprises are small-scale and lack competition. Ways to improve social enterprises include: 1. promote the concept of social enterprises and social entrepreneurs; 2. promote the social symbiotic system; 3. provide social enterprises with government funds and other resources.
\end{abstract}

Keywords: Social Enterprise, In-Depth Interview, Social Entrepreneurs

\section{Introduction}

Traditionally, the goal of business was profit maximization, and creation of social value was neglected. Many reports exist which indicate that some corporations have a positive image and strong financial reports, but in some cases negative information can also exist, such as enterprises placing excessive demands on their workforce or using environmentally harmful production processes.

Consequently, people with special social concerns and social missions have established nonprofit organizations (NPOs). The major objective of such organizations is to make up for social inefficiencies. Since NPOs rely on donations and government subsidies for their funding, while their mission statement may be clear they typically lack the financial resources to complete it. External environment influences availability of external resources. Simultaneously, new businesses have developed in America and Europe, known as social enterprises.

Generally, SEs aim to achieve specific social objectives, such as providing services (such as support services for the elderly) or products that meet specific community needs, creating employment and training opportunities for the socially disadvantaged, or protecting the environment, funding some social service, etc. The profits of such businesses are principally reinvested to achieve the target social objectives, rather than being distributed among shareholders. An aims of a good social enterprise comprise three components: to meet some community or local market need, to advance or achieve a specific social mission, and contribute to financial sustainability.

Social enterprises began to emerge in Taiwan in the 1990s. In most cases, their missions were to help farmers, residents of specific localities, and disadvantaged minorities. Social enterprises in Taiwan developed such that two main types existed. The first type was non-profit organizations (NPO) that became SEs and the other type were SEs established by social entrepreneurs. Over the years, the main operational problems faced by social enterprises have come to be accessing resources and funds, management challenges, task and mission challenges, and social perception challenges. This study uses in-depth interviews to survey high-level managers and social entrepreneurs of SEs in Taiwan. The main study objective is to classify social enterprises into different types to identify their problems and propose methods of improvement.

\section{Literature Review}

\subsection{Social Enterprise}

Social enterprises (SE) can be defined in numerous ways. 
The Social Enterprise Alliance (SEA) of the United States (2013) defines a social enterprise as a business whose primary purpose is the pursuit of common good. SEs use the methods and disciplines of business and the power of the marketplace to advance social, environmental and human justice agendas. In the UK, Social Enterprise UK (2013) defines a social enterprise as a business that trades to realize some social and/or environmental purpose. A SE will have a clearly defined 'social mission', which means it will know what difference it aims make, to who, and how. A SE will derive most or all of its income through selling goods or services, will also have clear rules about how profits are used, and will reinvest profits to further its 'social mission'. The Social Enterprise Council of Canada (SECC) of Canada (2013) defines a "social enterprise" as a business owned by a nonprofit organization, that is directly involved in the production and/or selling of goods and services for the combined purpose of income generation and the achievement of social, cultural, and/or environmental aims. Social enterprises are one more tool that non-profits can use to meet their mission of contributing to healthy communities. The Hong Kong Government (2013) defines social enterprises as businesses that achieve specific social objectives and whose profits are primarily reinvested to achieve the target social objectives, rather than being distributed to shareholders.

Ridley-Duff and Bull (2011) defined a social enterprise as an organization that applies commercial strategies to maximize improvements in human and environmental well-being, rather than maximizing shareholder profits. Alter (2007) discussed the difference between social enterprises and for-profit companies (Fig. 1). For-profit entities create social value, but their main motive is to achieve profit for distribution to shareholders. Nonprofits and social enterprises engage in commercial activities that generate economic value to fund social programs, and their main motivation is mission accomplishment, as dictated by stakeholder mandate. Alter also defined the sustainability strategy of social enterprises as being to adopt commercial methods to support social programs.

\begin{tabular}{|c|c|c|c|c|c|}
\hline \multicolumn{4}{|c|}{ Social Sustainability } & \multicolumn{2}{|c|}{ Economic Sustainability } \\
\hline $\begin{array}{l}\text { Traditional } \\
\text { Nonprofit }\end{array}$ & $\begin{array}{l}\text { Nonprofit with } \\
\text { Income- } \\
\text { Generating } \\
\text { Activities }\end{array}$ & $\begin{array}{c}\text { Social } \\
\text { Enterprise }\end{array}$ & $\begin{array}{l}\text { Socially } \\
\text { Responsible } \\
\text { Business }\end{array}$ & $\begin{array}{c}\text { Corporation } \\
\text { Practicing } \\
\text { Social } \\
\text { Responsibility }\end{array}$ & $\begin{array}{l}\text { Traditional } \\
\text { For-Profit }\end{array}$ \\
\hline$\leftarrow$ Purpose: & $\begin{array}{r}\text { ocial Value Crea } \\
\text { Sustainabili } \\
\text { Commero } \\
\text { Support soci }\end{array}$ & $\begin{array}{l}\text { on } \\
\text { Strategy: } \\
\text { I methods } \\
\text { programs }\end{array}$ & $\begin{array}{r}\text { Purp } \\
\leftarrow \text { Sustainat } \\
\text { "Doing }\end{array}$ & $\begin{array}{l}\text { se: Economic V: } \\
\text { lity Strategy: } \\
\text { vell by doing goo }\end{array}$ & Creation - \\
\hline
\end{tabular}

Figure 1. The Sustainability Strategy (Alter 2007)

\subsection{The Development of Social Enterprise}

Defourny \& Nyssens (2008) studied the trends and developments of social enterprises in Europe. The study found that social enterprises across Europe adopt different approaches, mainly within the third sector or the social economy, understood to mean embracing non-profit organizations, as well as co-operatives and related not-for-profit private enterprises. In both Italy and the UK, social enterprises thus are part of the third sector. Social enterprises are defined by their social purpose and their self-imposed limitations on profit distribution.

Statistical data from Mendell (2007) showed that The Social Enterprise Alliance in the United States has identified approximately 30 varieties of social enterprise there (classified according to area of involvement, such as community economic development, biomedical, media and communications, health, homelessness and housing, poverty and immigration, civil and human rights, substance abuse, sports and recreation, etc.). Mendell M. also surveyed 7,822 social enterprises in Québec. Typical social enterprises include early childhood centers, worker cooperatives, homecare services, and credit unions.

Chan et al. (2011) tracked the growth and development of social enterprises in Hong Kong and Taiwan from 2006 to 2010. Social enterprises in these territories are in a "growth stage", and are becoming increasingly diversified. Social enterprises in Hong Kong are more entrepreneurial and market driven than their Taiwanese counterparts. Meanwhile, owing to the development of civil society, community development social enterprises are more popular in Taiwan than in Hong Kong.

Haughton (2008) identified three business models adopted by most leading social enterprise.

Model 1: Leveraged non-profit venture

This kind of social enterprise is built to pursue social needs not met by market mechanisms or conventional businesses. Such social enterprises reinvest their profits into non-profit organizations to make up for the lack of government provision for public goods.

Model 2: Hybrid non-profit venture

Innovation occurs in each of the three business models, but the hybrid non-profit business model is most likely to be involved in innovation. This type of enterprises hopes that imaginative combination of non-profit and for-profit strategies will produce vigorous hybrid enterprises. Additionally, the more business-like aspects of a hybrid venture can make it appear more like a conventional business than a model 1 venture, in which there may be no realistic prospects of profit.

Model 3: Social business venture

Model 3 ventures are set up as for-profit businesses, either because philanthropic funds are unavailable, or because an obvious market exists. Entrepreneurs involved in such ventures seek investors interested in both financial and social returns. These entrepreneurs set up the venture as a business specifically to drive transformational social and/or environmental change.

\section{Classification of Social Enterprises}

According to previous studies, social enterprises are a hybrid of non-profit and for-profit organizations. Social 
enterprises are diverse, and while some closely resemble non-profit organizations, others more closely resemble for-profit organizations.

This study divides social enterprises into four types: benchmark targeting, Profit creating, self-sufficient and mission driven (Fig. 2). This classification is based on business operating situation.

\subsection{Self-Sufficiency Social Enterprise}

Most self-sufficient social enterprises are brand-new social enterprises or companies that lack management talent. Such enterprises can merely break even and lack the resources to realize their social mission or create profits.

\subsection{Mission Driven Social Enterprise}

Mission driven social enterprises closely resemble non-profit organizations, and always work on a specific social issue more deeply than profits creating social enterprises do. Such enterprises have ideal social missions but lack appropriate business models to realize those missions.

\subsection{Profit Creating Social Enterprise}

Profit creating social enterprises closely resembles for-profit organizations. Such enterprises have excellent profit earning ability, but sometimes ignore their social mission. The familiar problem faced by profit creating social enterprises is that they frequently can only help a small number of people, or only slightly mitigate a social problem. However, such enterprises create less social value than benchmark targeting social enterprises.

\subsection{Benchmark Targeting Social Enterprises}

Benchmark targeting social enterprise is the ideal form of social enterprises. Most of the Benchmark targeting social enterprises has mature business models. Benchmark targeting social enterprises not only achieve profits from their products or services but also reinvest those profits into realizing their social mission.

These four varieties of social enterprises can be represented graphically. The vertical axis represents degree to which the enterprise realizes its social mission, and the horizontal axis represents its profitability. Enterprise social mission and profitability are two key factors in assessing social enterprise success. Social enterprises with higher profitability can achieve its social mission faster. This matrix can provide a guide to help social entrepreneurs develop their businesses into benchmark social enterprises. Every social enterprise can approach benchmark social enterprise by improving its profitability or increasing its efforts to realize its social mission.

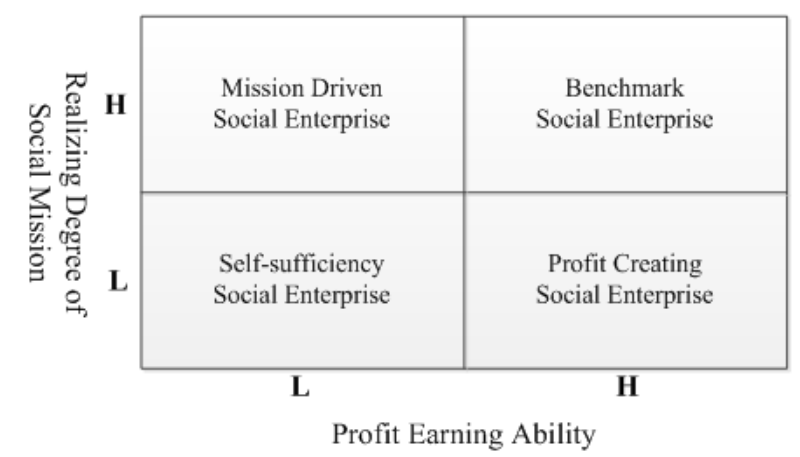

Figure 2. Social Enterprise Development Diagram

\section{Empirical Analysis of Social Enterprises in Taiwan}

This study uses in-depth interviews to survey senior managers and social entrepreneurs of SEs in Taiwan. Five academics, three government officials and 12 social entrepreneurs have conducted in-depth interviews. This study attempts to understand and classify different types of social enterprise to identify the problems of SEs and propose a matrix for improving them.

\subsection{Self-Sufficient Social Enterprises}

\subsubsection{Introduction}

$\mathrm{Wu}$ Wei Wu ("Five-Way-House"): Wu Wei Wu is a community charity shop located in Hualian County in Taiwan, and is run by local children and teenagers supported by volunteers. The teenagers who work at $\mathrm{Wu}$ Wei $\mathrm{Wu}$ are paid with product according to their hours worked. The primary aim of such an establishment is not profitability but to provide children in a remote area with an opportunity to experience the outside world, accumulate various interpersonal relationships and experiences, broaden their horizons, and ultimately increase their self-esteem.

\subsubsection{Discussion}

$\mathrm{Wu}$ Wei Wu currently resembles a non-profit organization. The major goal of the organization is community care and helping teenagers increase their life experience. The social enterprise development diagram presented in this study suggests $\mathrm{Wu}$ Wei $\mathrm{Wu}$ can first better realize its social mission, and then enhance its profitability. Wu Wei Wu can design an annual summer volunteer project to attract volunteers from different regions. The project can not only increase the reputation of the organization but also provide a stable pool of human resources to draw on. Eventually, $\mathrm{Wu}$ Wei Wu can increase its profits through developing one or two typical products with local characteristics, such as handmade cookies, or accessories.

\subsection{Mission Driven Social Enterprise}

\subsubsection{Introduction}

1. The Garden of Hope Foundation: The Garden of Hope Foundation is a non-government, non-profit organization 
established in 1988 to help disadvantaged girls and young women. The organization particularly targets sex industry workers, as well as victims of sexual abuse and family violence. The Garden of Hope Foundation provides services such as employment training, social work and legal assistance to empower girls and young women so that they can better realize their full potential and take control of their lives. Because of the inability of these organizations to earn profits, government funding and donations continue to dominate the financial resources of The Garden of Hope Foundation.

2. News and Market: News and Market started in 2012, and its social mission is to raise awareness of local agriculture. News and Market established a website that provides news on agriculture, food safety and environmental issues, and offers land-friendly products. The organization has its own reporters to write news, and its news platform remains its operational focus. In the future, News and Market hopes to pursue product innovation to improve the lives of those involved in agriculture.

3. Taiwan Social Enterprise Innovation Association: The Taiwan Social Enterprise Innovation Association is a promotional group associated with $\mathrm{Fu}$ Jen Catholic University that was established in 2009. The mission of the organization is to promote social enterprise in Taiwan. The organization has held numerous activities related to social enterprises, such as speeches by social entrepreneurs, social enterprise fairs, institutional visits by social enterprises, etc. Taiwan Social Enterprise Innovation Association also cooperates with the social enterprise research center of Fu Jen Catholic University to hold workshops and seminars, and publish related research articles.

\subsubsection{Discussion}

Most mission-driven social enterprises are working on specific social issues. Such enterprises are always more deeply involved in issues than are profit seeking social enterprises. However, most such mission-driven social enterprises lack business models that link the social problems with which they are concerned to consumers. This study thus suggests two development paths that mission driven social enterprises can follow. Such enterprises do not require a complete business model as do benchmark social enterprises, but must find ways to earn financial resources to support their basic operation. For example, the Taiwan Social Enterprise Innovation Association can earn profits by selling consulting services and holding workshops.

Additionally, mission driven social enterprises can also build their own business models to gain some of the benefits of benchmark social enterprises. For example, the Garden of Hope Foundation can develop products based on designs from young women they have helped. Such products can not only increase the enterprise profile, but their sales can contribute to enterprise profitability. News and Market can publish their own periodical publications or can transformation to a platform that can be used by all sellers of green products.

\subsection{Profit Creating Social Enterprise}

\subsubsection{Introduction}

Oko Green: Oko Green was founded in 2007, and its major product is fair trade coffee. The social mission of Oko Green is to promote social justice and environmental protection. Oko Green encourages its customers to consider how goods are produced and directly helps farmers increase their incomes by promoting and selling fair-trade coffee. The major sales channels of Oko Green are physical stores and online shops. So far the organization is entirely self-funded, and receives no allowances or subsidies. Most consumers consider Oko Green a good coffee supplier but ignore the fair trade issue, because the distance between coffee producers and consumers is too great.

\subsubsection{Discussion}

Oko Green has excellent business management skills, but suffers a major problem in that consumers are not directly connected with the fair trade issue which makes it harder for them to realize its social mission. This study thus suggests that Oko Green promote its mission through improving its website to provide further information on product origin and producer stories.

\subsection{Benchmark Targeting Social Enterprise}

\subsubsection{Introduction}

1. CAREUS: The full name of CAREUS is the Children Are Us Foundation. CAREUS was established in 2001 and its mission is to help mentally disabled individuals access life-long education and care, and to assist them in being socialized to earn job opportunities in society. Furthermore, CAREUS hope to change the social stereotypes faced by mentally disabled individuals through various activities. CAREUS operates like a business, and is unlike traditional foundations that rely primarily on donations. CAREUS earns profits from its bakery and restaurant, and to date has worked extensively to help those with mental disabilities.

2. Homemakers' Union and Consumer Cooperative: The Homemakers' Union and Consumer Cooperative was founded by those interested in environmental protection and healthy eating. The financial resources of the organization come from member annual fees, and the organization reduces the purchase price of green products through direct and large scale purchases from producers. This social enterprise also promotes dietary and environmental protection knowledge through a self-published magazine. Many producers in the cooperative have improved their lives through the help of the Homemakers' Union and Consumer Cooperative.

3. Dialogue in the dark TPE: Dialogue in the Dark (DiD) was founded in Germany in 1988, and has developed numerous services and training courses that are 
delivered the dark. Dialogue in the dark TPE is the Taiwan branch of DiD. DiD TPE offers numerous different courses such as cooking in the dark, birthdays in the dark, and education program for student. The courses are unique is that all the instructors are visually disabled. The courses not only provide participants with new and valuable experiences but also generate job opportunities for the visually disabled.

4. WILDGREEN: WILDGREEN was established in 2009 , with pollution-free organic cotton clothing as its main product. The social mission of WILDGREEN is to promote environmental protection and protect consumer and farmer health. The founder insists that the products are $100 \%$ Taiwan made, and all the materials are said to be ecologically friendly. WILDGREEN primarily relies on online sales, and also promotes its social mission through involvement in the holiday environmental protection market.

\subsubsection{Discussion}

Benchmark targeting social enterprises possesses strong ability to earn profits and realize their social mission. However, they must pay attention to environmental change and fix their business strategy. Continuous change helps social enterprises to continuously operate and realize their social mission.

\section{Conclusion}

According to empirical analysis of social enterprises in Taiwan, this study discovered that the social enterprise development diagram can help social entrepreneurs to analyze the present situation of their enterprises. Social entrepreneurs must assess the degree to which they have realized their social mission, as well as their profitability and determine the quadrant in which they are located. They can then decide on a future development strategy. Social enterprises must apply their business skills to solve specific social problems. The best condition an enterprise can be in is one where it simultaneously enhances its degree of realization of its social targets and its profitability. If it is hard to simultaneously pursue both these goals, social entrepreneurs must decide whether the development direction depends on their location in the social enterprise development diagram.

The in depth interviews reveal some findings relevant to understanding the development and operational overview of Taiwanese social enterprises.

1. Lack of understanding and mainstream marketing of social enterprises

In the interview, when social entrepreneurs sought to promote the mission of their social enterprises, they found that most Taiwanese did not know what social enterprises were. This raised the question of what such organizations were doing. Social entrepreneurs generally need to invest considerable time to disseminate their ideas and knowledge to enhance visibility.

\section{Personal struggle}

In Taiwan, most social entrepreneurs run their businesses independently, and all of them struggle. Frequently their businesses lack economies of scale, which limits their social impact.

3. Persistent focus on main enterprise goals

Social enterprise establishment in Taiwan aims to promote positive issues or solve social problems. Although numerous difficulties exist in operating social enterprises, such as environment problems, and limited resources, and social entrepreneurs typically persist in the face of these problems, and continue to run their businesses and pursue their missions.

4. Small-scale operations

Most social enterprises in Taiwan are small-scale. This arises not only from cost control considerations, but also because small-scale businesses are highly mobile and flexible.

According to the characteristics of social enterprises in Taiwan, the following suggestions are made to benefit the future development of social enterprises in Taiwan.

\section{Symbiosis}

The social enterprises interviewed in this study usually work alone. However, cooperation among such social enterprises, such as through projects like Dialog in the Dark that can have an associated dining component, could support products like those from CAREUS and Oko Green. Once a group of loyal customers are obtained, enterprise profitability stabilizes and can help offset the disadvantages of small scale through a steady stream of revenue.

\section{Universalism}

The social enterprises interviewed in this study claimed that most consumers had no idea what a social enterprise was. Therefore they had to spend considerable time on educating consumers, and methods to raise awareness and understanding of social enterprises should be considered.

3. Academic literature

Social enterprise research is an emerging field within social research. Numerous topics in this area can be researched, and researchers can cooperate with social entrepreneurs to perform further empirical study to improve social enterprise operations.

\section{Government intervention}

Most social enterprises face difficulties such as lack of funds, particularly when they are immature. In such situations, government allowances can help these enterprises get on track. Moreover, laws and regulations focused on the area in which the enterprise works may be imperfect, and this may create further problems for enterprise development. Another point is that non-profit organizations frequently lack sufficiently specific positioning, and the general public may have insufficient knowledge of the areas in which they work, creating consumer confusion. Generally, more complete legal support and financial indemnification can help stabilize such enterprises.

Although this empirical study focuses on social enterprises in Taiwan, the social enterprise development 
diagram developed is suitable for application to social enterprises elsewhere. As discussed in this study, the main task of social enterprises is to apply business skills to solve specific social problems. However, the key factor to achieving this task is enterprise social mission and profitability. All social enterprises can evolve into benchmark targeting enterprises following the social enterprise development diagram.

\section{Acknowledgements}

The authors would like to thank the National Science Council of the Republic of China, Taiwan for financially supporting this research under Contract No. NSC 100-2632-H-030-001.

\section{References}

[1] Alter, K., (2007), Social enterprise typology. United State: Virtur Ventures LLC.

[2] Bidet, E., and Eum, H.S., (2011), "Social enterprise in South Korea: history and diversity". Social Enterprise Journal, 7(1), $69-85$

[3] CAREUS, http://www.c-are-us.org.tw. 18.03.2013.

[4] Chan, K. T., Kuan, Y.Y., and Wang, S.T., (2011), "Similarities and divergences: comparison of social enterprises in Hong Kong and Taiwan", Social Enterprise Journal, 7(1), 33-49.

[5] Defourny, J., and Nyssens, M., (2008), "Social enterprise in Europe: recent trends and developments", Social Enterprise Journal, 4(3): 202-228.

[6] Dialogue in the dark TPE, http://www.dialogue-in-the-dark-tpe.com. 18.03.2013.
[7] Haughton, C., (2008), "The Edge of Reason". Director, 61, 70-74.

[8] Home Affairs Department Hong Kong, http://www.social-enterprises.gov.hk, 18.03.2013.

[9] Homemakers' Union and Consumer Cooperative, http://www.hucc-coop.tw. 18.03.2013.

[10] Mendell, M., (2007), Social Enterprise: A North American Perspective, Concordia University, Canada.

[11] News and Market, http://www.newsmarket.com.tw. 18.03.2013.

[12] Oko Green, http://www.okogreen.com.tw. 18.03.2013.

[13] Ridley-Duff, R. J., and Bull, M., (2011), Understanding Social Enterprise: Theory and Practice, London: Sage Publications.

[14] Social Enterprise Alliance. http://www.se-alliance.org/ what-is-social-enterprise, 18.03.2013.

[15] Social Enterprise UK. http://www.socialenterprise.org.uk/ about/ about-social-enterprise, 18.03.2013.

[16] Taiwan Social Enterprise Innovation Association, http://www.management.fju.edu.tw/subweb/seietw. 18.03.2013

[17] The Garden of Hope Foundation, http://www.goh.org.tw. 18.03.2013.

[18] The Social Enterprise Council of Canada. http://www.enterprisingnonprofits.ca/what-social-enterprise, 18.03.2013.

[19] WILDGREEN, http://www.wildgreen.tw. 18.03.2013.

[20] Wu Wei Wu, http://www.5wayhouse.org. 18.03.2013. 